\title{
Three new species of picobiine mites (Acari: Syringophilidae) parasitising African flycatchers (Aves: Muscicapidae)
}

\author{
Maciej Skoracki • Piotr Solarczyk • \\ Bozena Sikora
}

Received: 27 April 2012/Accepted: 25 May 2012

(C) The Author(s) 2012. This article is published with open access at Springerlink.com

\begin{abstract}
Three new species of quill mites of the subfamily Picobiinae Johnston \& Kethley, 1973 (Acari: Syringophilidae) are described from African flycatchers (Passeriformes: Muscicapidae): Picobia cichladusa n. sp. on Cichladusa arquata Peters and P. myrmecocichla n. sp. on Myrmecocichla arnotti (Tristram), both from Tanzania, and P. echo n. sp. on Cossypha heuglini Hartlaub from the Democratic Republic of the Congo.
\end{abstract}

\section{Introduction}

The family Syringophilidae Lavoipierre, 1953 includes highly specialised parasites of birds. These mites live and reproduce inside the quills of various feather types (e.g. primaries, secondaries, coverts, rectrices and body feathers), feeding on the soft tissue fluids of their hosts by piercing the calamus wall with their long and flexible cheliceral digits (Kethley, 1971). The host-parasite relationships of syringophilids and their biodiversity are still poorly known. To date the family includes 269

M. Skoracki $(\bowtie) \cdot$ B. Sikora

Department of Animal Morphology, Faculty of Biology, Adam Mickiewicz University, Umultowska 89,

61-614 Poznan, Poland

e-mail: skoracki@amu.edu.pl

P. Solarczyk

Department of Biology and Medical Parasitology, Faculty of Medicine I, Poznan University of Medical

Sciences, 10 Fredry Street, 61-701 Poznan, Poland species of 53 genera recorded from more than 180 bird species belonging to 69 families of 21 orders from all of the geographical regions, except for the Antarctic (Skoracki, 2011; Skoracki \& OConnor, 2010; Skoracki et al., 2011, 2012). However, the actual number of syringophilid species is estimated to be at least 5,000 based on the species numbers of their potential hosts (Johnston \& Kethley, 1973). In contrast to members of the subfamily Syringophilinae Lavoipierre, 1953, which mainly inhabit the flight feathers, most species of the subfamily Picobiinae Johnston \& Kethley, 1973, except for species of Calamincola Casto, 1978, occupy quills of the body feathers. This difference is likely a result of a basal divergence at an early stage of syringophilid evolution (Skoracki et al., 2004).

The subfamily Picobiinae includes 36 species of five genera (excluding three species assigned as incertae sedis): these include Picobia Haller, 1878 with 19 species parasitising birds of the orders Passeriformes, Piciformes and Upupiformes; Rafapicobia Skoracki, 2011 with two species found on passerines; Neopicobia Skoracki, 2011 with 10 species found on Passeriformes, Columbiformes and Psittaciformes; Columbiphilus Kivganov \& Sharafat, 1995 with four species, one known from a columbiform host and the remaining species from galliforms; and Calamincola Casto, 1977 with a single species described from a cuculiform host (Casto, 1977; Kivganov \& Sharafat, 1995; Fain et al., 2000; Skoracki et al., 2004; Skoracki, 2011; Skoracki \& Sikora, 2011; Sikora et al., 2011; Glowska \& Skoracki, 2011; Glowska et al., 2011). 
To date, only one picobiine species, Rafapicobia zinitra Skoracki, 2011, has been described from muscicapid hosts, i.e. Saxicola rubetra (Linnaeus) and Ficedula hypoleuca (Pallas). In this paper, we describe three new species of Picobia found on African flycatchers.

\section{Materials and methods}

The material used in the present study was collected from dry bird skins housed in the ornithological collection of the Bavarian State Collection of Zoology (ZSM), Munich, Germany. Mites were extracted with sharp, fine tweezers through a longitudinal cut made in the quill. Before mounting, mites were softened and cleared in $10 \%$ lactic acid at $60^{\circ} \mathrm{C}$ for $2-3$ days. For light microscope studies, mites were mounted on slides in Faure's medium and examined under an Olympus BH-2 light microscope with differential interference contrast (DIC) optics. Drawings were made with camera lucida. All measurements, including the figure scale-bars, are given in micrometres. The idiosomal setation follows Grandjean (1939), as adapted for the Prostigmata by Kethley (1990). The system of nomenclature for leg setation follows that proposed by Grandjean (1944), as adapted for the Syringophilidae by Bochkov et al. (2008) and Skoracki (2011). Bird taxonomy and nomenclature of birds follow Clements (2007). Specimen depositories and reference numbers are cited using the following abbreviations: AMU, A. Mickiewicz University, Natural History Collection, Poznan, Poland; ZSM, Bavarian State Collection of Zoology, Munich, Germany.

\section{Family Syringophilidae Lavoipierre, 1953 Subfamily Picobiinae Johnston \& Kethley, 1973}

\section{Genus Picobia Haller, 1878}

\section{Picobia cichladusa n. sp.}

Type-host: Cichladusa arquata Peters (Passeriformes: Muscicapidae).

Type-locality: Tanzania, Soga, 16 July 1960, coll. Th. Andersen.

Type-material: Female holotype (non-physogastric form) and paratypes: 1 female (non-physogastric form), 2 females (physogastric form), 1 male, 2 nymphs. Mites removed by M. Skoracki. Host specimen deposited in the ZSM. All type-material is deposited in the ZSM (Reg. No. ZSM 20112002), except for 1 female paratype (physogastric form) in the AMU (Reg. No. AMUSYR.371).

Etymology: The name of this species refers to the generic name of the host.

Description (Figs. 1-9)

Non-physogastric female (Figs. 1-5). [Based on holotype and 1 paratype.] Total body length 485 (555). Gnathosoma. Hypostomal apex rounded, without shoulders (Fig. 3). Infracapitulum apunctate. Movable cheliceral digit edentate posteriorly, 145 (145) long. Each medial branch of peritremes with 3-4 chambers; each lateral branch with 7 chambers (Fig. 4). Stylophore 185 (180) long. Podomers of palps densely punctate. Idiosoma. Propodonotal shield punctate, divided into 2 narrow lateral and single oval median shields. Length ratio of setae vi:ve: si is 1.3:1:1.3. Bases of setae $v i$ and $v e$ situated at same transverse level. Setae $c l$ located slightly anterior to level of setae $s e$. Dorsal setae of idiosoma and legs lightly beaded (Fig. 5). Pygidial shield well developed, punctate. Setae $f 21.4$ times longer than $f 1$. Setae $f 1$ 1.4-1.5 times longer than $h l$. Aggenital setae $a g l$ situated anterior to level of setae ag2. Length ratio of setae ag1:ag2:ag3 1.3:1:2. Genital plate present, punctate. Genital lobes present. Pseudanal setae $p s 1$ and $p s 2$ subequal in length. Genital setae filiform, situated on genital lobes, subequal to pseudanal setae (Fig. 6). All coxal fields well sclerotised, apunctate. Setae $4 c 1.3$ times longer than $3 c$. Length ratios of setae $3 b: 3 c$ and $4 b: 4 c$ 1:2.3 and 1:3.2, respectively. Legs. Antaxial and paraxial members of claws subequal in size. Setae $t c^{\prime}$ and $t c^{\prime \prime}$ of legs III-IV subequal in length. Lengths of setae: vi 115 , ve 90 (90), si 115 (120), se 210 (180), c1 220 (215), c2 195 (180), d1 205 (180), d2 210 (195), e2 150 (155),fl 70 (65), f2 100 (95), h1 50, h2 >200, agl 55 (60), ag2 40 (45), ag3 85 (90), g1 30 (30), ps1 30 (30), ps2 30 (30), $t c^{\prime} I I I-I V 50$ (55), tc IIIII-IV 50 (55), l'RIII 30 (25), $3 b$ (30), 3c 70 (65), $4 b 30$ (30), 4c 95 (95).

Physogastric female. [Based on 1 paratype.] Body, vermiform in outline, 895 long. Other characters as in non-physogastric form.

Male (Figs. 7-9). [Based on 1 paratype.] Total body length 435. Gnathosoma. Hypostomal apex rounded. 


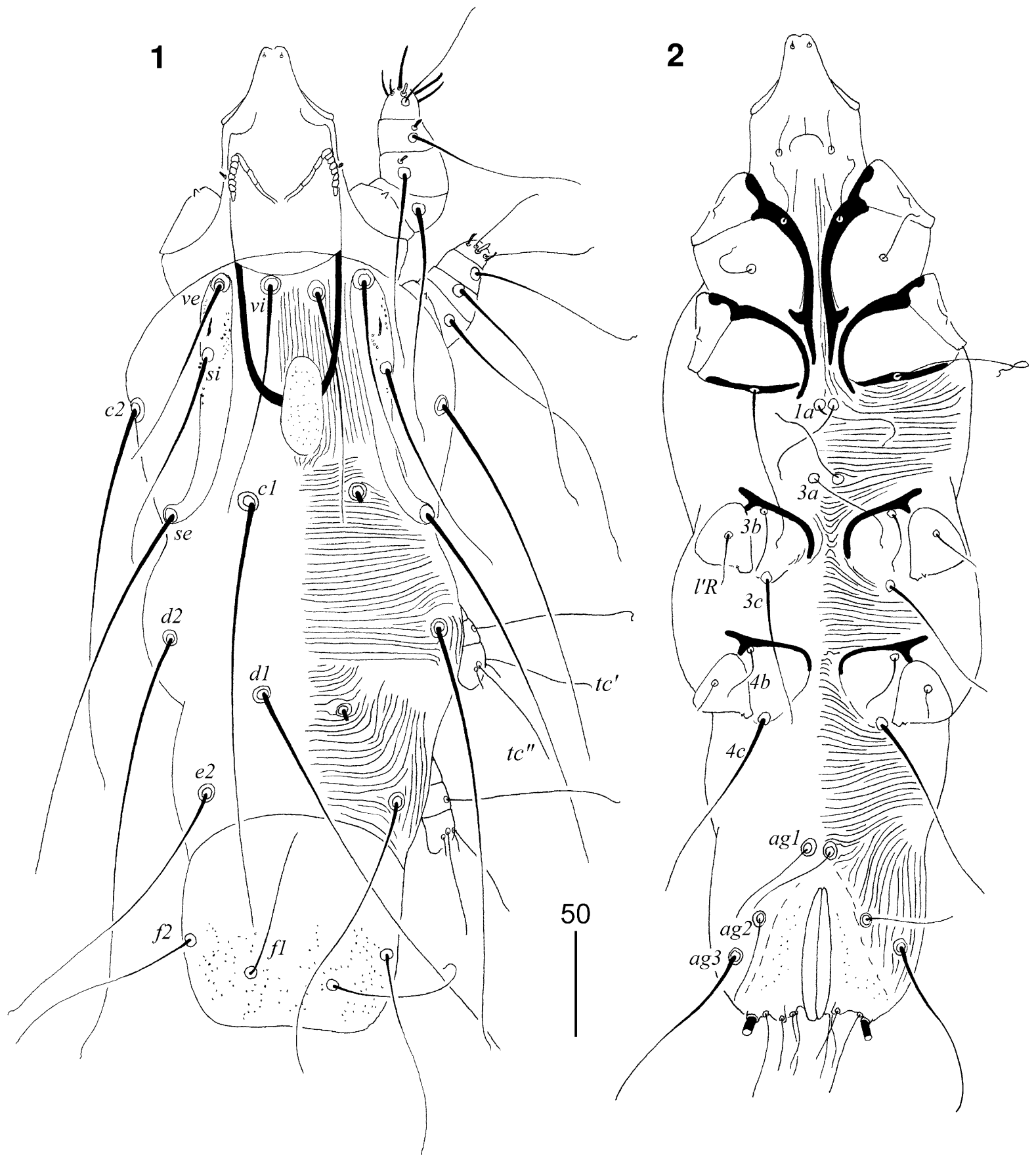

Figs. 1, 2 Picobia cichladusa n. sp., female: 1, dorsal view; 2, ventral view

Infracapitulum apunctate. Stylophore 100 long. Each medial branch of peritremes with 3 chambers; each lateral branch with 7-8 chambers (Fig. 7). Idiosoma. Propodonotal shield divided into 2 narrow and sparsely punctate lateral shields and unpaired oval shield situated in middle of propodonotum. Length ratio of setae vi:ve:si are 1.3:1:1.3. Idiosomal setae vi, ve, si, se, $c 1, c 2$ and $d 2$ slightly beaded; other idiosomal setae smooth. Bases of setae $v i$ and ve situated at same transverse level. Setae $c l$ and se situated at same transverse level. Hysteronotal shield well developed, entire, apunctate, bearing bases of 


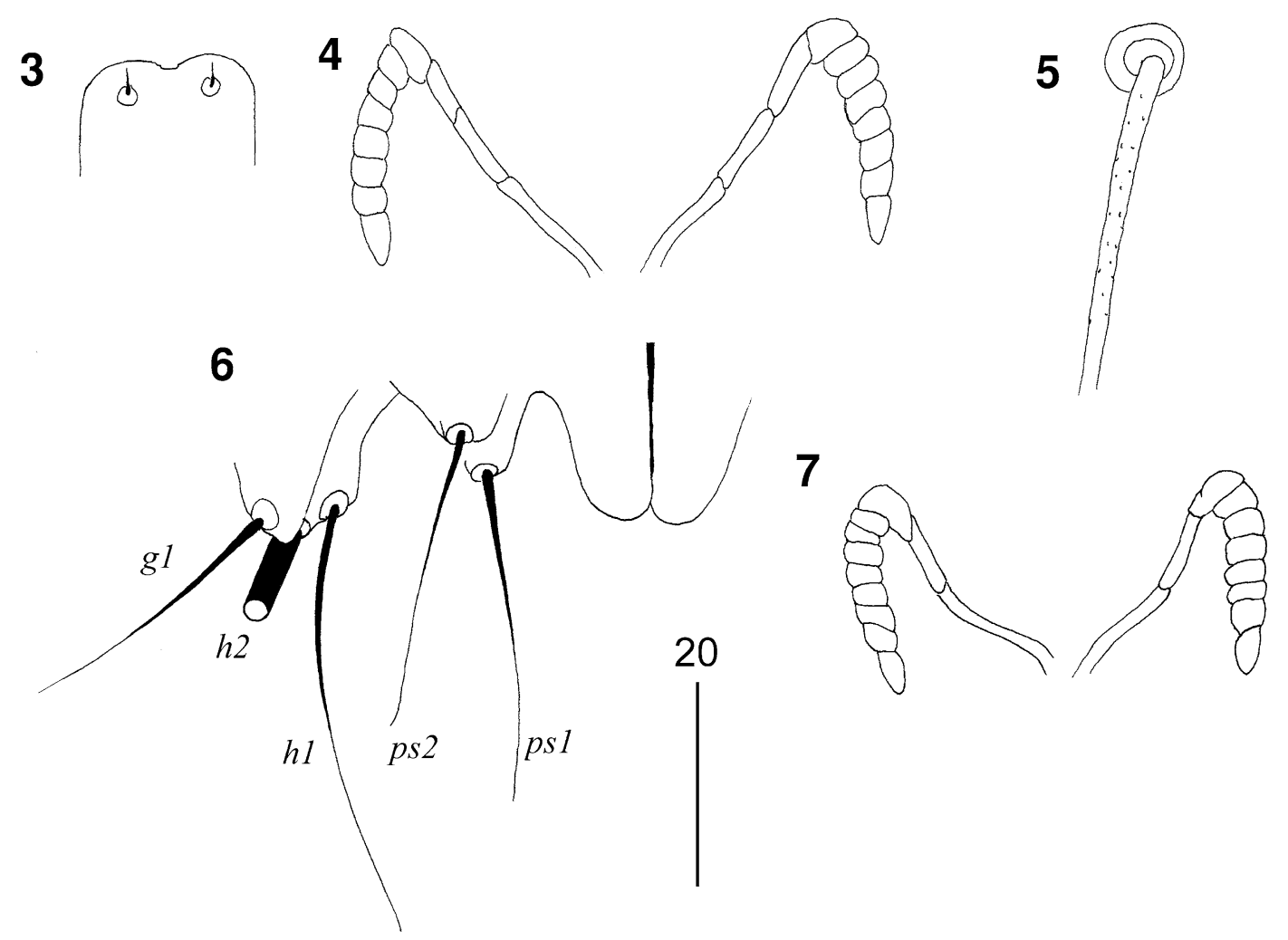

Figs. 3-7 Picobia cichladusa n. sp.: (3-6), female: 3, hypostomal apex; 4, peritremes; 5, propodonotal seta ve; 6, terminal opisthosoma in ventral view; (7), male: 7 , peritremes

setae $d 1$ and $e 2$. Setae $d 2$ about 9 times longer than $d 1$ and $e 2$. Pygidial shield well sclerotised, apunctate. Setae $h 2$ about 15 times longer than $f 2$. Two aggenital plates present, bearing bases of setae agl on posterior margin. Setae ag1 1.8 times longer than ag2. All coxal fields well sclerotised and apunctate. Setae $4 c 1.4$ times longer than $3 c$. Length ratios of setae $3 b: 3 c$ and $4 b: 4 c 1: 2.3$ and 1:2.6, respectively. Legs. Dorsal setae of all legs slightly beaded. Setae $t c^{\prime}$ and $t c^{\prime \prime}$ of legs IIIIV subequal in length. Lengths of setae: vi 100, ve 75, si 100, se 140, cl 165, c2 130, dl 15, d2 140, e2 15, f2 $15, h 2>140$, agl 45, ag2 25, tc $I I I-I V$ and $t c^{\prime \prime} I I I-I V$ 45, l'RIII 25, $3 b 20,3 c 45,4 b 25,4 c 65$.

\section{Differential diagnosis}

Picobia cichladusa $\mathrm{n}$. sp. is morphologically similar to P. currucae Skoracki \& Magowski, 2001 described from Sylvia curruca (Linnaeus) (Passeriformes: Sylviidae) in Poland (Skoracki \& Magowski, 2001). In females of both species: the hypostomal apex is rounded; the peritremes are M-shaped; the movable cheliceral digit is edentate posteriorly; the pygidial and genital shields are well developed; the genital setae are filiform and situated on well developed genital lobes; and the hysteronotal is absent. This new species differs from $P$. currucae by the following characters: in females of $P$. cichladusa, aggenital setae ag2 are situated posterior to the level of setae $a g 1$; genital setae $g 1$ and pseudanal setae $p s 1$ and $p s 2$ are subequal in length; the propodonotal shield is punctate and divided into two narrow lateral shields and a single oval median shield. Whereas, in females of $P$. currucae, aggenital setae $a g 1$ and $a g 2$ are situated at the same transverse level; genital setae $g l$ are 2-2.5 times longer than pseudanal setae $p s 1$ and $p s 2$; and the propodonotal shield is apunctate and divided only into two narrow lateral shields, i.e. the unpaired median shield is absent.

\section{Picobia echo n. sp.}

Type-host: Cossypha heuglini Hartlaub (Passeriformes: Muscicapidae). 

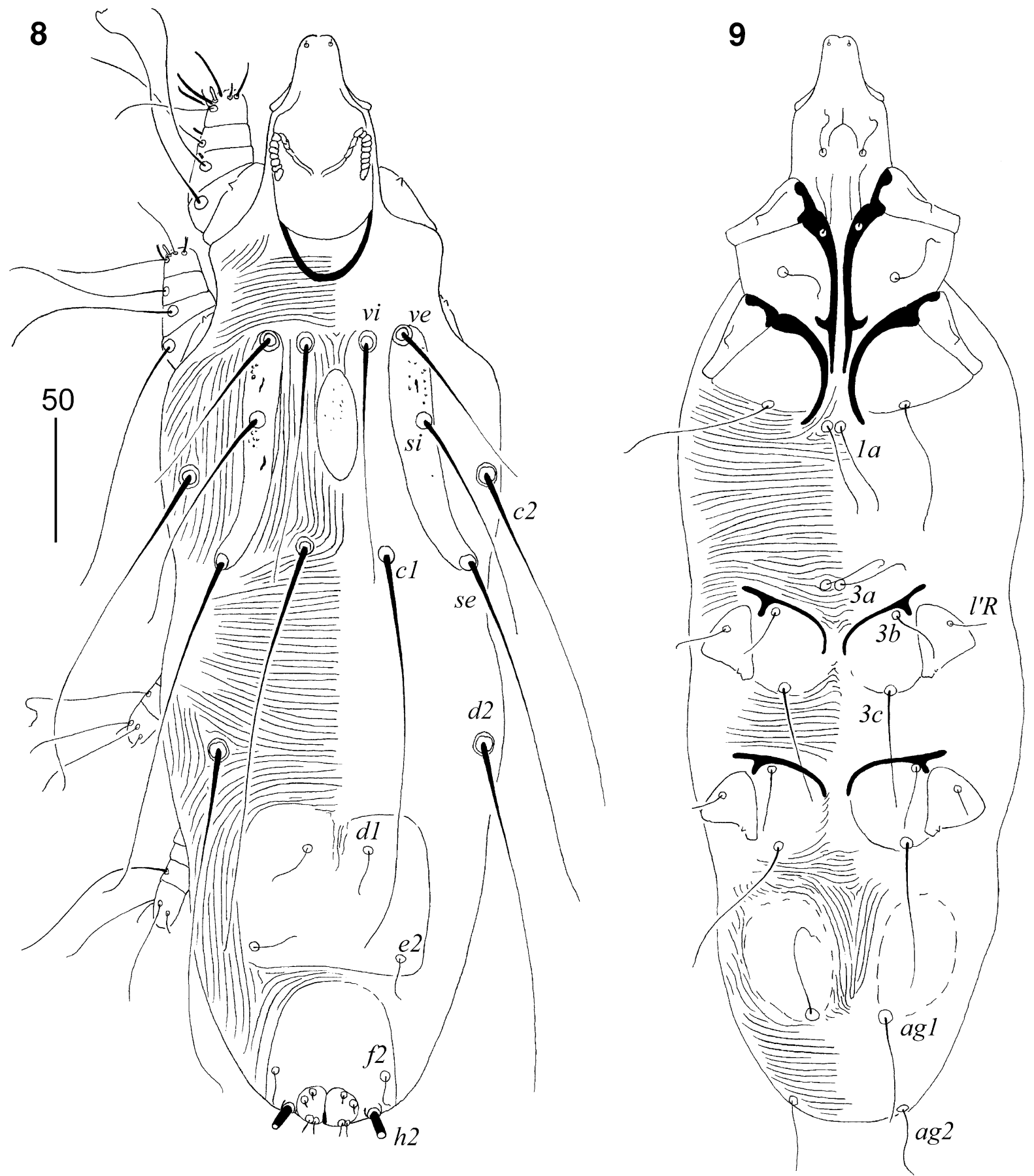

Figs. 8, 9 Picobia cichladusa n. sp., male: 8, dorsal view; 9, ventral view

Type-locality: D. R. Congo, South Kivu Prov., Bukavu, 7 August 1969, coll. P. Kunkel.

Type-material: Female holotype (non-physogastric form) and paratypes: 4 females (physogastric form), 2 males, 2 nymphs and 1 larva. Host specimen is deposited in the ZSM. Mites removed by M. Skoracki. All material is deposited in the ZSM (Reg. No. ZSM 20112010), except 1 female paratype (physogastric form) in the AMU (Reg. No. AMU-SYR.372). 


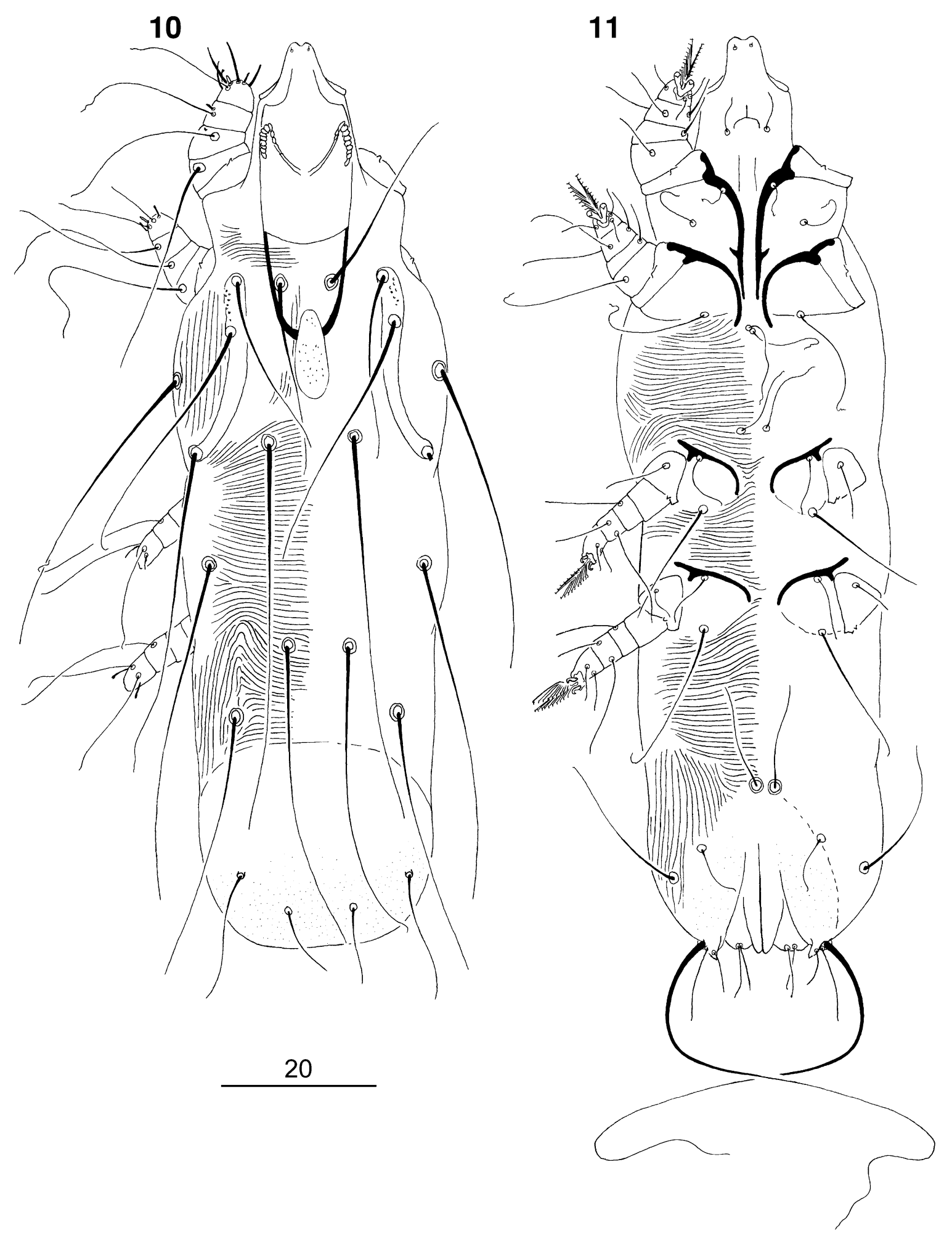

Figs. 10, 11 Picobia echo n. sp., female: 10, dorsal view; 11, ventral view 
12

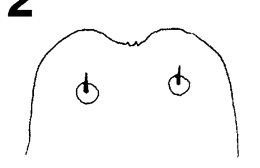

13

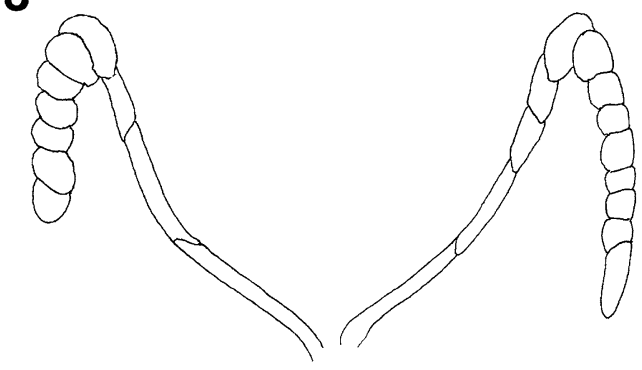

14

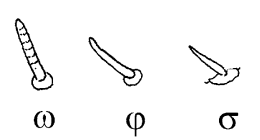

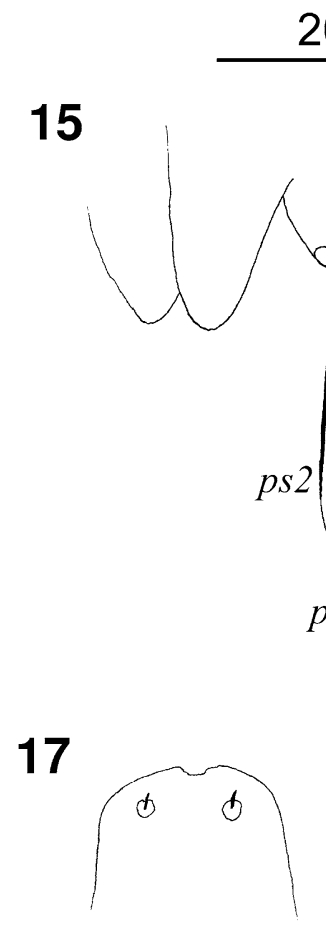

20

15
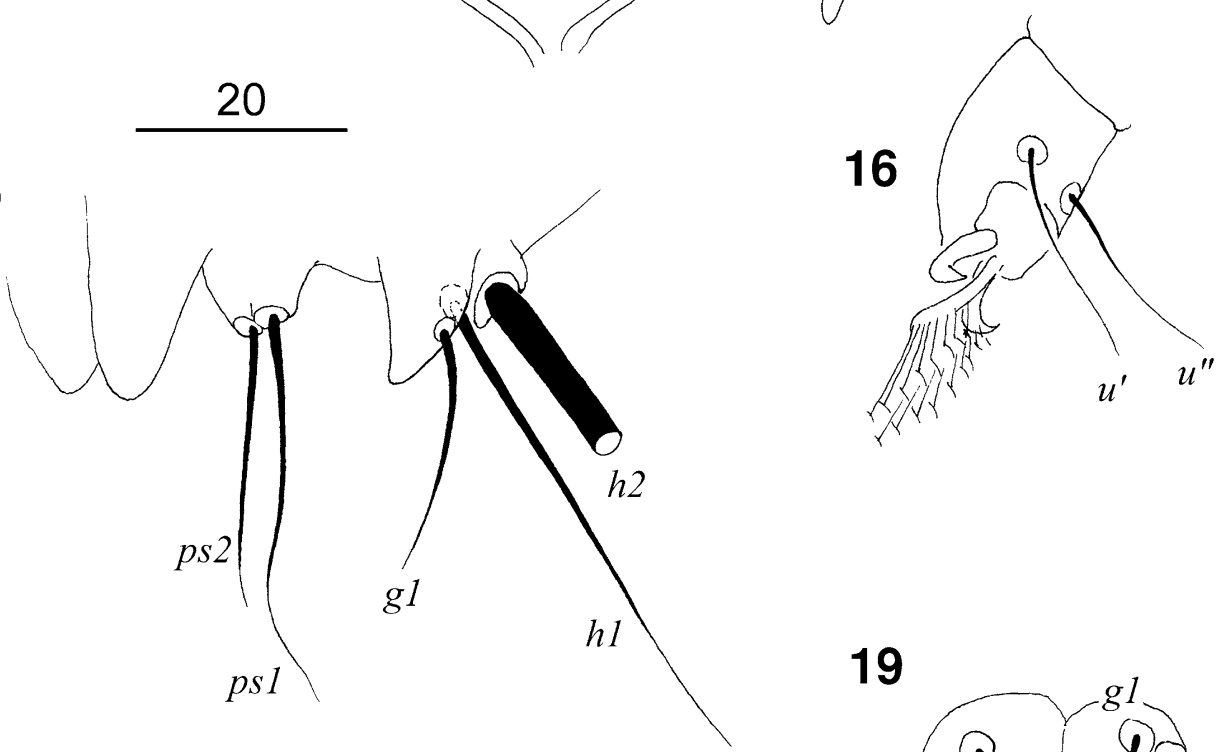

19

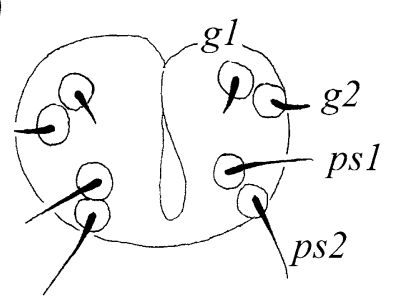

Figs. 12-19 Picobia echo n. sp.: (12-16) female: 12, hypostomal apex; 13, peritremes; 14, solenidia of leg I; 15, terminal opisthosoma in ventral view; 16, tarsus III in ventral view; (17-19) male: 17, hypostomal apex; 18, peritremes; 19, genito-anal region

Etymology: The name of this species derives from the Greek $\varepsilon \chi \omega \dot{\omega}(\bar{e} c h o)$, "sound".

Description (Figs. 10-21)

Non-physogastric female (Figs. 10-16). [Based on holotype.] Total body length 565. Gnathosoma. Hypostomal apex rounded, without shoulders (Fig. 12). Infracapitulum apunctate. Movable cheliceral digit edentate posteriorly, 145 long. Each medial branch of peritremes with 4-5 chambers; each lateral branch with 6-8 chambers (Fig. 13). Stylophore 185 long. Podomers of palps densely punctate. Idiosoma. Propodonotal shield punctate, divided into 2 narrow lateral and single oval median shields. Length ratio of setae vi:ve:si is 1:1:1.4. Bases of setae vi and ve situated at same transverse level. Setae $c 1$ set slightly anterior to level of setae se. Dorsal setae of idiosoma (except terminal setae h2) lightly beaded. Pygidial shield well developed, punctate. Setae $f 2$ twice as long as $f 1$. Setae $f l$ and $h l$ subequal in length. Aggenital setae agl situated anterior to level of setae $a g 2$. Length ratio of setae ag1:ag2:ag3 1.4:1:2. Genital plate present, punctate. Genital lobes present. Pseudanal setae $p s 1$ 1.4 times longer than $p s 2$. Genital setae filiform, situated on genital lobes (Fig. 15). All coxal fields well sclerotised, apunctate. Setae $4 c$ not significant (1.1-1.2 times) longer than $3 c$. Length ratios of setae 


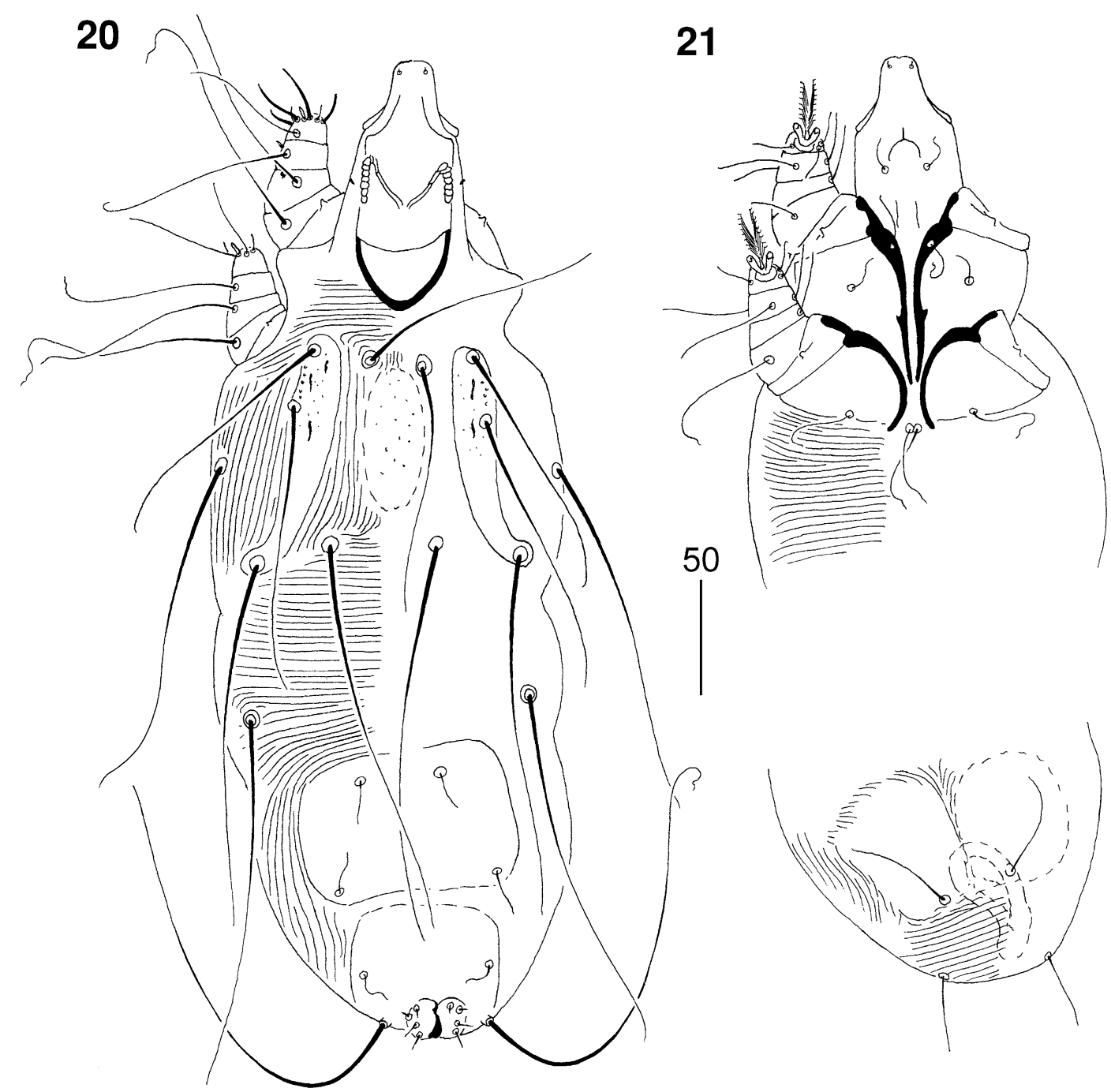

Figs. 20-21 Picobia echo n. sp., male: 20, dorsal view; 21, propodosoma and opisthosoma in ventral view

$3 b: 3 c$ and $4 b: 4 c$ 1:2.4. Legs. Antaxial and paraxial members of claws subequal in size (Fig. 16). Setae $t c^{\prime}$ and $t c^{\prime \prime}$ of legs III-IV subequal in length. Dorsal setae of all legs lightly beaded. Lengths of setae: vi 125 , ve 125, si 180, se 215, cl 240, c2 205, dl 190, d2 220, e2 185,fl 45, f2 90, hl 45, h2 >200, agl 65, ag2 45, ag3 90, g1 20, ps1 35, ps2 25, tc'III-IV 60, tc'III-IV 60, l'RIII 35, $3 b$ 35, 3c 85, 4b 40, 4c 95.

Physogastric female. [Based on 1 paratype.] Body, vermiform outline, 1,100 long. Other characters as in non-physogastric form.

Male (Figs. 17-21). [Based on 2 paratypes.] Total body length 380-410. Gnathosoma. Hypostomal apex rounded (Fig. 17). Infracapitulum apunctate.
Stylophore 105 long. Each medial branch of peritremes with 3-4 chambers; each lateral branch with 7-8 chambers (Fig. 18). Idiosoma. Propodonotal shield punctate, divided into 2 narrow lateral shields and one unpaired oval shield situated in middle of propodonotum. Length ratio of setae vi:ve:si 1:1:1.1-1.2. Idiosomal setae vi, ve, si, se, $c 1, c 2$ and $d 2$ slightly beaded; other setae smooth. Bases of setae $v i$ and ve situated at same transverse level. Setae $c l$ situated slightly anterior to level of setae se. Hysteronotal shield well developed, entire, apunctate, bearing bases of setae $d 1$ and $e 2$. Setae $d 2$ about 7 times longer than $d l$ and $e 2$. Pygidial shield well sclerotised, apunctate. Setae $h 2$ about 13 times longer than $f 2$. Two aggenital plates present, situated close to each other, 


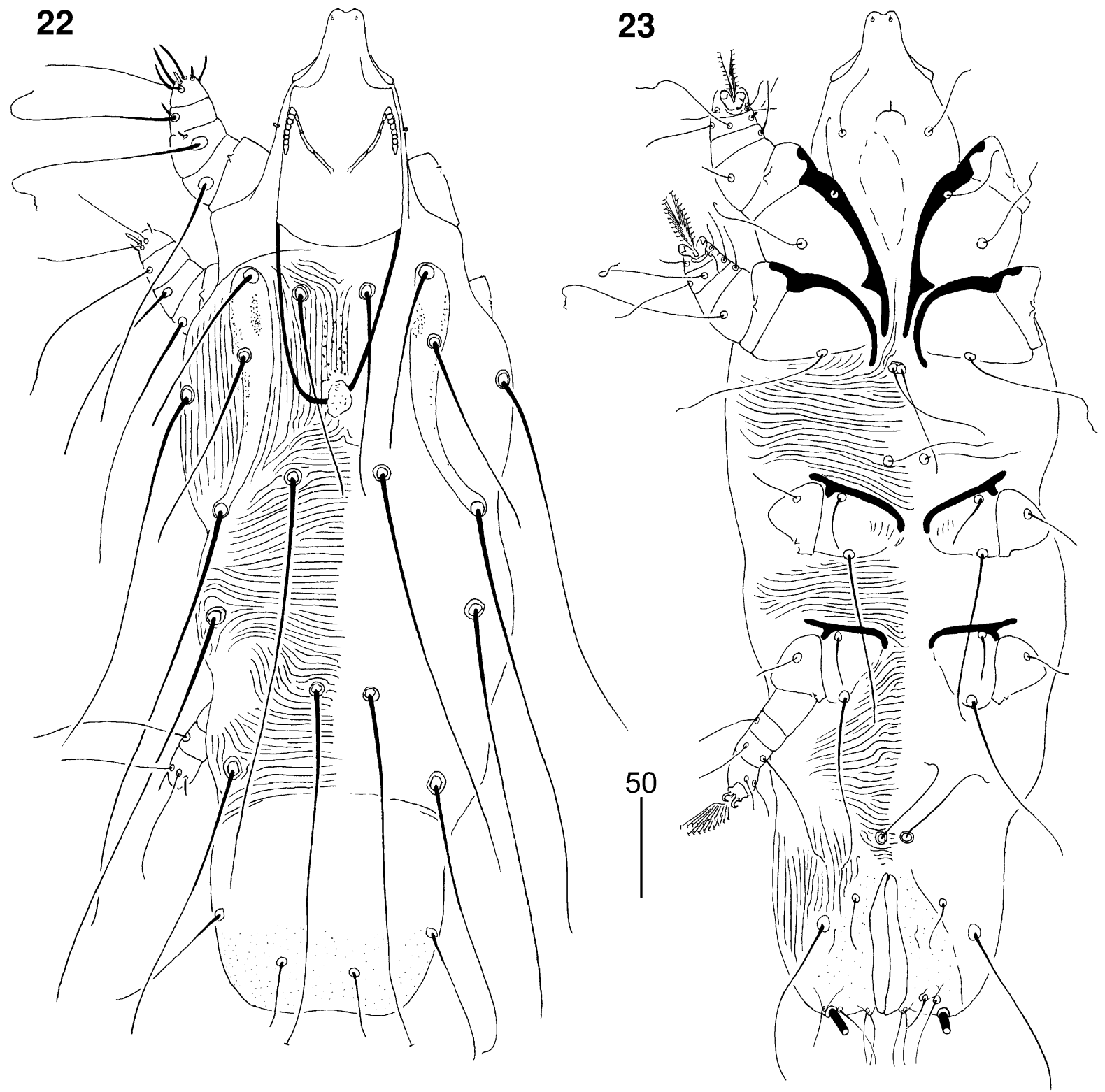

Figs. 22, 23 Picobia myrmecocichla n. sp., female: 22, dorsal view; 23, ventral view

bearing bases of setae agl. Setae agl 1.3-1.8 times longer than ag2. All coxal fields well sclerotised and apunctate. Setae $4 c$ not significant (1.1-1.2 times) longer than $3 c$. Legs. Dorsal setae of all legs slightly beaded. Setae $t c^{\prime}$ and $t c^{\prime \prime}$ of legs III-IV subequal in length. Lengths of setae: vi 105, ve 100-115, si 100-125, se 155-160, cl 165, c2 150-160, d1 20, d2 140, e2 20, f2 15, h2 160-190, agl 45, ag2 25-35, $t c^{\prime} I I I-I V$ and $t c^{\prime \prime} I I I-I V$ 50-55, $l^{\prime}$ RIII 25, 3b 25, 3c 50, $4 b 25,4 c$ 55-60.
Differential diagnosis

This species is morphologically similar to $P$. cichladusa n. sp., described above, and is distinguished by the following characters: in females of $P$. cichladusa, setae $v i$ are longer than ve (1.3 times); setae si and $v i$ are subequal in length; the length ratio of setae $f 1: f 2$ is $1: 1.4$; and the lengths of setae se, $e 2$ and $f 1$ are 115-120, $150-155$ and 60-70 $\mu \mathrm{m}$, respectively. In females of $P$. $e c h o$ n. sp., setae $v i$ and $v e$ are subequal in length; setae $s i$ 


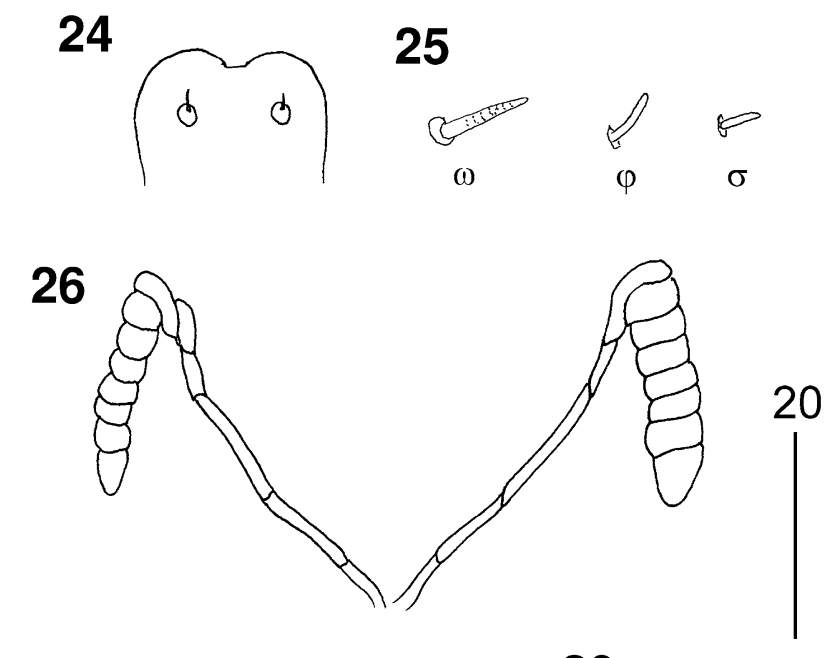

28
29
27
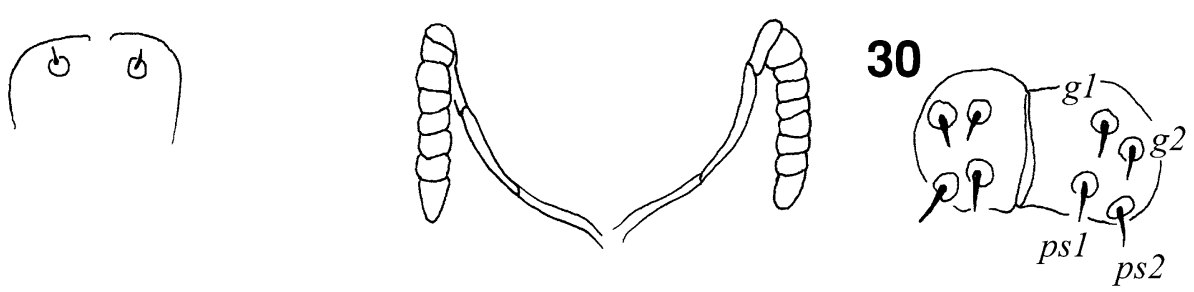

Figs. 24-30 Picobia myrmecocichla n. sp.: (24-27) female: 24, hypostomal apex; 25, solenidia of leg I; 26, peritremes; 27, terminal opisthosoma in ventral view; (28-30) male: 28, hypostomal apex; 29, peritremes; 30, genito-anal region

are 1.4 times longer than $v i$; the length ratio of setae $f 1: f 2$ is $1: 2$; and the lengths of setae $s e, e 2$ and $f 1$ are 180,185 and $45 \mu \mathrm{m}$, respectively.

\section{Picobia myrmecocichla n. sp.}

Type-host: Myrmecocichla arnotti (Tristram) (Passeriformes: Muscicapidae).

Type-locality: Tanzania, 10 September 1963, coll. Th. Andersen.

Type-material: Female holotype (non-physogastric form) and paratypes: 1 female (non-physogastric form), 2 females (physogastric form), 2 males, 1 nymph. Mites removed by M. Skoracki. Host specimen is deposited in the ZSM. All material is deposited in the ZSM (Reg. No. ZSM 20112011), except 1 female paratype (physogastric form) in the AMU (Reg. No. AMU-SYR.375).

Etymology: The name of this species refers to the generic name of the host.
Description (Figs. 22-32)

Non-physogastric female (Figs. 22-27). [Based on holotype and 1 paratype.] Total body length 530 (520). Gnathosoma. Hypostomal apex rounded, without shoulders (Fig. 24). Infracapitulum apunctate. Movable cheliceral digit edentate posteriorly, 160 (160) long. Each medial branch of peritremes with 5-6 chambers; each lateral branch with 7 chambers (Fig. 26). Stylophore 200 (195) long. Podomers of palps densely punctate. Idiosoma. Propodonotal shield divided into 2 narrow and punctate lateral shields; median shield reduced to small sclerite or absent. Length ratio of setae vi:ve:si is 1.4-1.6:1:1.4-1.6. Bases of setae $v i$ situated slightly posterior to level of setae ve. Setae $c l$ located anterior to level of setae $s e$. Dorsal setae of idiosoma and legs lightly beaded. Pygidial shield well developed, punctate. Setae $f 2$ 2-2.3 times longer than $f l$. Setae $f l$ and $h l$ subequal in length. Aggenital setae agl situated anterior to level of setae ag2. Length ratio of setae ag1:ag2:ag3 2:1:2.7. Genital plate punctate. Genital lobes present. 

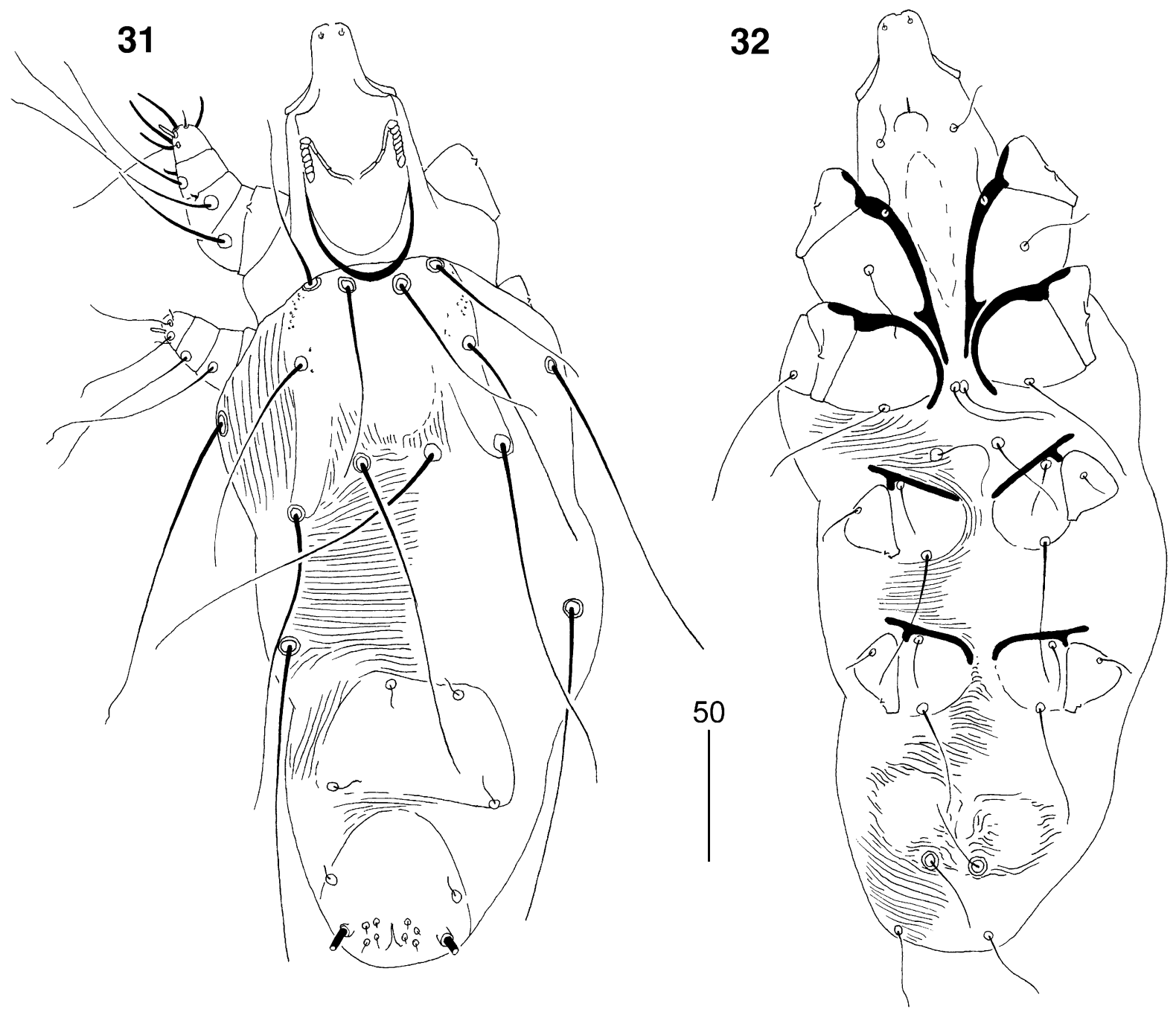

Figs. 31, 32 Picobia myrmecocichla n. sp., male: 31, dorsal view; 32, ventral view

Pseudanal setae $p s 1$ and $p s 2$ subequal in length. Genital setae filiform, situated on genital lobes. All coxal fields well sclerotised, apunctate. Setae $4 c$ slightly (1.1-1.2 times) longer than $3 c$. Length ratios of setae $3 b: 3 c$ 1:2.5-2.7. Legs. Antaxial and paraxial members of claws subequal in size. Setae $t c^{\prime}$ and $t c^{\prime \prime}$ of legs III-IV subequal in length. Lengths of setae: vi 110 (125), ve 80 (80), si 110 (125), se 215 (220), cl 235 (215), c2 (205), d2 225 (225), e2 145 (140), f1 35 (30), f2 70 (70), h1 35 (30), h2 >200, agl 55 (60), ag2 (30), ag3 75 (80), g1 25, psl (30), ps2 25, tc'III-IV 55 (55), $t c^{\prime \prime} I I I-I V 55$ (55), l'RIII 30 (25), $3 b 30$ (30), 3c 75 (80), $4 c 90$ (90).
Physogastric female. [Based on 1 paratype.] Body, vermiform outline, 1,050 long. Other characters, excluding pygidial shield clearly punctate, as in nonphysogastric form.

Male (Figs. 28-32). [Based on 2 paratypes.] Total body length 435. Gnathosoma. Hypostomal apex rounded (Fig. 28). Infracapitulum apunctate. Stylophore 95-105 long. Each medial branch of peritremes with 3 chambers; each lateral branch with 7-8 chambers (Fig. 29). Idiosoma. Propodonotal shield not divided, long-sleeved shirt-like, punctate near bases of setae ve and si. Length ratio of setae vi:ve:si 
are 1.2-1.3:1:1.4-1.5. Idiosomal setae vi, ve, si, se, $c 1$, $c 2$ and $d 2$ slightly beaded; other setae smooth. Bases of setae $v i$ situated slightly posterior to level of setae ve. Setae $c l$ situated anterior to level of setae. Hysteronotal shield well developed, trapezoidal in shape, apunctate, bearing bases of setae $d 1$ and $e 2$. Setae $d 28-10$ times longer than $d 1$ and $e 2$. Pygidial shield well sclerotised, apunctate. Setae $h 2$ about 15 times longer than $f 2$. Two aggenital plates present, weakly developed; bases of setae agl situated near these plates. Setae $a g 1$ and $a g 2$ subequal in length. All coxal fields well sclerotised and apunctate. Length ratio of setae $3 b: 4 b: 3 c: 4 c$ 1:1:2.3:2-2.3. Legs. Dorsal setae of all legs lightly beaded. Setae $t c^{\prime}$ and $t c^{\prime \prime}$ of legs III-IV subequal in length. Lengths of setae: vi 70, ve 55-60, si 80-85, se 140, cl 135, c2 130, d1 15-20, d2 120, e2 15-20, f2 10, h2 150, agl 30, ag2 25-30, $t c^{\prime} I I I-I V$ and $t c^{\prime \prime} I I I-I V$ 40-45, $l^{\prime}$ RIII 25, $3 b$ 20, 3c 45, $4 b 20,4 c 40$.

\section{Differential diagnosis}

This new species is morphologically similar to P. cichladusa n. sp., described above by the presence of setae $v i$ and $s i$ which are subequal in length in the females. It differs from $P$. cichladusa as follows: in females of $P$. myrmecocichla n. sp., the propodonotal median shield is reduced or absent; the lengths of setae $f 1$ and $f 2$ are 30-35 and $70 \mu \mathrm{m}$, respectively; the length ratio of setae ag 1:ag2:ag3 is 2:1:2.7; and setae $f 1$ and $h l$ are subequal in length; in males, the propodonotal shield is not divided; the aggenital plates are strongly reduced and setae agl are situated near these plates; and setae $v i$ are $70 \mu \mathrm{m}$ long. In females of P. cichladusa, the propodonotal median shield is well sclerotised; the lengths of setae $f 1$ and $f 2$ are $60-70$ and 95-100 $\mu \mathrm{m}$, respectively; the length ratio of setae ag1:ag2:ag3 is 1.3:1:2; and setae $f 1$ are 1.4-1.5 times longer than $h 1$; in males, the propodonotal shield is divided into three sclerites; the aggenital plates are well developed and the bases of setae $a g l$ are situated on these plates; and setae $v i$ are $100 \mu \mathrm{m}$ long.

Acknowledgements We would like to express our appreciation to Prof. Gerhard Haszprunar (Director of the ZSM) and to the staff of the ornithological section (ZSM), Ruth Diesner and Markus Unsöld, for making available samples of dry bird skins for the present study. The research was supported by the Polish Committee for Scientific Research (Grant No. NN 303802540). The senior author received support from the
Synthesys Project (http://www.synthesys.info/), which is financed by the European Community Research Infrastructure Action under FP7 (BE-TAF-1687).

Open Access This article is distributed under the terms of the Creative Commons Attribution License which permits any use, distribution, and reproduction in any medium, provided the original author(s) and the source are credited.

\section{References}

Bochkov, A. V., OConnor, B. M., \& Wauthy, G. (2008). Phylogenetic position of the family Myobiidae within the Prostigmata (Acari: Acariformes). Zoologischer Anzeiger, 247, 15-45.

Casto, S. D. (1977). Cuculiphilus lobatus gen. n., sp. n. representing a new subfamily of quill mites (Acarina: Syringophilidae) from the groove-billed ani, Crotophaga sulcirostris (Cuculiformes: Cuculidae). Southwestern Naturalist, 22, 169-176.

Clements, J. F. (2007). The Clements checklist of birds of the world (6th Edition). Ithaca: Cornell University Press, 864 pp.

Fain, A., Bochkov, A. V., \& Mironov, S. V. (2000). New genera and species of quill mites of the family Syringophilidae (Acari: Prostigmata). Bulletin de l'Institut Royal des Sciences Naturelles de Belgique, 70, 33-70.

Glowska, E., Dragun-Damian, A., \& Dabert, J. (2011). Picobia dziabaszewskii sp. nov. (Acari, Syringophilidae) - combined description (morphology with DNA barcode data) of a new quill mite species parasitizing Garrulax formosus (Passeriformes: Leiothrichidae). Zootaxa, 3224, 57-61.

Glowska, E., \& Skoracki, M. (2011). Two new quill mite species (Acari, Cheyletoidea, Syringophilidae) parasitizing Dinemellia dinemelli (Rüppell) (Passeriformes, Ploceidae). Zootaxa, 3114, 63-68.

Grandjean, F. (1939). Les segments postlarvaires de l'hysterosoma chez les oribates (Acariens). Bulletin de la Société Zoologique de France, 64, 273-284.

Grandjean, F. (1944). Observations sur les acariens de la famille Stigmaedae. Archives des Sciences Physiques et Naturelles, 26, 103-131.

Johnston, D. E., \& Kethley, J. B. (1973). A numerical phenetic study of the quill mites of the family Syringophilidae (Acari). Journal of Parasitology, 59, 520-530.

Kethley, J. B. (1971). Population regulation in quill mites (Acarina: Syringophilidae). Ecology, 52, 1113-1118.

Kethley, J. B. (1990). Acarina: Prostigmata (Actinedida). In: Dindal, D. L (Ed.) Soil biology guide. New York: Wiley and Sons, pp. 667-754.

Kivganov, D. A., \& Sharafat, G. S. (1995). [Review of the family Syringophilidae (Acari) with the description of new genera and species]. Zoologichesky Zhurnal, 74, 82-91. [In Russian].

Sikora, B., Fajfer, M., \& Skoracki, M. (2011). Quill mites (Acari: Syringophilidae) from mimid birds (Aves: Mimidae). Zootaxa, 3027, 29-38.

Skoracki, M. (2011). Quill mites (Acari: Syringophilidae) of the Palaearctic region. Zootaxa, 2840, 1-415. 
Skoracki, M., Bochkov, A. V., \& OConnor, B. M. (2011). Notes on quill mites (Acariformes, Syringophilidae) from aquatic birds in North America. Acta Parasitologica, 56, 325-330.

Skoracki, M., Bochkov, A. V., \& Wauthy, G. (2004). Revision of the quill mites of the genus Picobia Haller, 1878 (Acari: Syringophilidae) with notes on their host-parasite relationships. Insect Systematics \& Evolution, 35, 155-176.

Skoracki, M., \& Magowski, W. (2001). Two new species of quill mites of the genus Picobia (Acari: Prostigmata: Syringophilidae) from passerine birds of Poland. Acarina, 9, 113-119.
Skoracki, M., \& OConnor, B. M. (2010). New taxa of quill mites (Acari: Cheyletoidea: Syringophilidae). Zootaxa, 2341, $1-32$.

Skoracki, M., \& Sikora, B. (2011). Quill mites (Acari: Syringophilidae) associated with galliform birds (Aves: Galliformes). Zootaxa, 2966, 13-30.

Skoracki, M., Sikora, B., \& Ozminski, M. (2012). A new quill mite species (Acari: Syringophilidae) parasitising tinamous (Aves: Tinamiformes). Systematic Parasitology, 81, 109-113. 